\section{The effect of simulated acid rain on growth of root systems of Scindapsus aureus}

\author{
Thomas V. EI-Mallakh, Yonglin Gao, \\ Rif S. El-Mallakh
}

Department of Psychiatry and Behavioral Sciences, University of Louisville School of Medicine, KY, USA

\begin{abstract}
The effect of acid rain on root systems has not been adequately studied. This study examined the effect of simulated acid rain on the root systems of a common tropical vine. Cuttings $(10 \mathrm{~cm})$ of Scindapsus aureus were grown for 7 weeks without soil in deionized water in which the $\mathrm{pH}$ was adjusted with sulfuric acid to $2.25,3.26,4.4,5.5$, and 6.5 (no acid added). Tap water ( $\mathrm{pH}=8.1$ ) was also examined. Root number and total root length were measured at baseline and after 7 weeks. Stock water at the initial $\mathrm{pH}$ was used to maintain the water level weekly. There were no differences in either root number or root length in any of plants in $\mathrm{pH} 4.4$ or greater. Plants at the two lowest $\mathrm{pH}$ settings did not produce significant roots. Healthy plants $(\mathrm{pH} \geq 4.4)$ acidified the water's $\mathrm{pH}$ in which they were growing to 4.4-5.4. The $\mathrm{pH}$ of plants in more acidic $\mathrm{pH}$ remained unchanged. Some roots prefer a more acidic $\mathrm{pH}$. If this is characteristic is widespread, the effect of acid rain on plant root systems may be less severe than anticipated.
\end{abstract}

\section{Introduction}

Acid rain is the decrease in $\mathrm{pH}$ of rain water resulting from human activity. It results from the burning of fossil fuels, releasing $\mathrm{NO}_{\mathrm{x}}$ and $\mathrm{SO}_{\mathrm{x}}{ }^{1}$ When these pollutants dissolve in rain water they form nitric acid and sulfuric acid. Atmospheric $\mathrm{SO}_{2}$ has increased 20 fold globally since the $1800 \mathrm{~s}^{2}$

Simulated acid rain with $\mathrm{pH}<3.0$ has been shown to have deleterious effects on germination and growth of various plant species. ${ }^{3-5}$ Roots can be affected, generally with reduced root growth at very low $\mathrm{pH}(<3) .^{5,6}$ In these experiments, plants are either grown in soil, ${ }^{5}$ or are germinated from seed. ${ }^{6}$ The effect of simulated acid rain on plant cuttings has not been previously studied.

In the current study we chose to examine the effect of a component of acid rain, sulfuric acid, on plant cuttings. We did this so that we could directly examine root growth, which we could do without disturbing the plant. Additionally, cuttings are an injured plant, and since injuries are common in nature, this allowed us to examine the effect of acid rain on root growth of an injured plant. Both of these have not been previously done.

\section{Materials and Methods}

Four experimental pHs $(2.25,3.26,4.4$, and 5.5), and two control pHs (6.5 no acid added to deionized water and 8.1 local tap water) were examined. To reduce the number of variables introduced in this experiment, only sulfuric acid was used to simulate acid rain, rather than a combination of both sulfuric acid and nitric acid. Sulfuric acid was added to deionized water to create stock $\mathrm{pH}$-adjusted water which was made in one initial batch, and was used to water the plants for the duration of the experiment. Stock water, a large amount of water adjusted to the desired $\mathrm{pH}$, was used to top-off the plants' water source, so that the $\mathrm{pH}$ would not change over time due to evaporation or dilution with addition of deionized water. Deionized water was used in the experiments because rain is essentially made of distilled water; many chemicals are added to tap water that are not found in rain and can react with sulfuric acid. However, we utilized a tap water control because deionized water also deprives cuttings of needed minerals, and we were concerned that the mineral deficiency would adversely effect the experiment.

Cuttings of the money plant, Scindapsus aureus, were utilized. This plant was used because it does well when cut. Healthy mature plants were the source of $10 \mathrm{~cm}$ cuttings. Cuttings were placed in $15 \mathrm{cc}$ plastic tubes in each of the experimental $\mathrm{pH}$ solutions. All experiments were performed in triplicate.

The total number of new roots (both primary and secondary), and the total length of the root system was recorded weekly for 7 weeks, but the primary outcome measure was the final measures. Student t-test was used to compare all the results at week 7 .

\section{Results}

Nearly all cuttings in $\mathrm{pHs} \geq 4.4$ sprouted roots (with the exception of one cutting in $\mathrm{pH}$ 6.5). The number (Figure 1A) and cumulative length (Figure 1B) of these roots was not significantly different in any of the $\mathrm{pHs} \geq 4$.4. No roots sprouted in the most acidic solution ( $\mathrm{pH}=2.25)$, and an average of only 2 roots/plant sprouted in those growing in $\mathrm{pH}=3.26$ (Figure 1A). There was no significant growth of the stem or the leaves of
Correspondence: Rif S. El-Mallakh, Mood Disorders Research Program, Department of Psychiatry and Behavioral Sciences, University of Louisville School of Medicine, MedCenter One, 501 East Broadway, Suite 340, Louisville, KY 40202, USA.

Tel.: +1.502.852.1124 - Fax: +1.502.852.5098

E-mail: rselma01@louisville.edu

Key words: acid rain, roots, Scindapsus aureus, sulfuric acid.

Acknowledgements: the authors wish to thank Dr. Dave Robinson of Bellarmine University for insightful and provocative discussions. His encouragement was instrumental in the completion of this work.

Contributions: TEM, performed most of experimental work, helped write the paper; YG, supervised experimental work, helped write the paper; REM,designed study, oversaw performance of the experimental work, performed statistical analysis, helped write the paper.

Conflict of interests: the authors declare no potential conflict of interests.

Received for publication: 19 November 2013

Revision received: 13 January 2014.

Accepted for publication: 23 April 2014.

This work is licensed under a Creative Commons Attribution NonCommercial 3.0 License (CC BYNC 3.0).

(OCopyright T.V. El-Mallakh et al., 2014

Licensee PAGEPress srl, Italy

International Journal of Plant Biology 2014; 5:5187 doi:10.4081/pb.2014.5187

any of the plants. Plants growing at less acidic $\mathrm{pHs}$ acidified their growing water to a range of 4.4-5.4 (Table 1). Plants in the two most acidic pHs did not alter their waters' pH (Table 1). In one cutting at $\mathrm{pH}$ of 6.5 in which no roots sprouted, the water remained at a $\mathrm{pH}$ of 6.5 .

\section{Discussion and Conclusions}

$S$. aureus cuttings exposed to simulated acid rain in the $\mathrm{pH}$ range of 4.4-8.1 showed no differences in root germination and growth (Figure 1). There were no significant stem or leaf growth in any of the plants in this brief study. Cuttings exposed to $\mathrm{pH} \leq 3.26$ did poorly with no or minimal root growth and deterioration of the existing leaf growth. While this study utilized a tropical vine, other investigators have noted that plants generally do well when exposed to simulated acid rain $\mathrm{pH} \geq 4 .^{3-5}$ Corn (Zea mays) or Eucalyptus seedlings experience a promotion of root growth at $\mathrm{pH}$ of 4.5 compared to $6.5^{7,8}$ These data may be relevant 
Table 1. The $\mathrm{pH}$ of the water used to treat $S$. aureus cuttings. The original $\mathrm{pH}$ is the $\mathrm{pH}$ of the water added to the plant vessel, the ending $\mathrm{pH}$ is the $\mathrm{pH}$ of the water in which the plant grew.

\begin{tabular}{lc} 
Original pH & Ending pH \\
\hline 2.25 & 2.3 \\
3.26 & 3.3 \\
\hline 4.4 & 4.4 \\
5.5 & 5.4 \\
\hline 6.5 & 4.4 \\
8.1 & 4.6 \\
\hline
\end{tabular}

to the study of acid rain since the average $\mathrm{pH}$ of acid rain in the eastern United States in 2007 is approximately $4.4 .^{9}$ This rain water $\mathrm{pH}$ is an improvement that is due to reduction of $\mathrm{SO}_{\mathrm{x}}$ emissions, ${ }^{1}$ but the problem continues. While the current study, and several others, ${ }^{3-5,7,8}$ suggests that the roots of many flowering plants may be able to tolerate the current level of acid rain, acid rain has been shown to be quite destructive, particularly to aquatic environments. 1,10

$S$. aureus cuttings may actually prefer mildly acidic environments. Plants placed in less acidic, or basic environments, acidified their water environment to approximately $\mathrm{pH}$ of 5 (Table 1). This appeared to be an active process of the roots, since the one cutting at 6.5 that did not germinate roots, did not alter final pH. Roots of plants are known to secrete hydrogen ions, ${ }^{11,12}$ and this is sufficient to dissolve calcium carbonate in limestone rocks. ${ }^{13}$ Simulated acid rain has been shown to inhibit proton extrusion by roots. ${ }^{14}$ There are several physiological constraints that promote proton extrusion, but nutrient deficiency is most relevant to current design. ${ }^{13}$

Environmental iron and phosphate deficiency induce acid secretion by plant roots. ${ }^{13}$ Most of the cuttings in the current study were placed in deionized water - a nutrient poor environment.

The current study has several shortcomings. The most important of which is the use of $S$. aureus. This tropical vine has advantages for laboratory study, but is not reflective of North American flora. Consequently, generalization of the findings is somewhat limited. However, other researchers have reported similar findings with different flowering plants, ${ }^{3-6}$ suggesting the $\mathrm{pH}$ sensitivity and preference described herein may be a common characteristic of many plants. Additionally, the current study used cuttings placed in water. This design allows for ease of investigation of roots, but is not reflective of plants growing in soil.

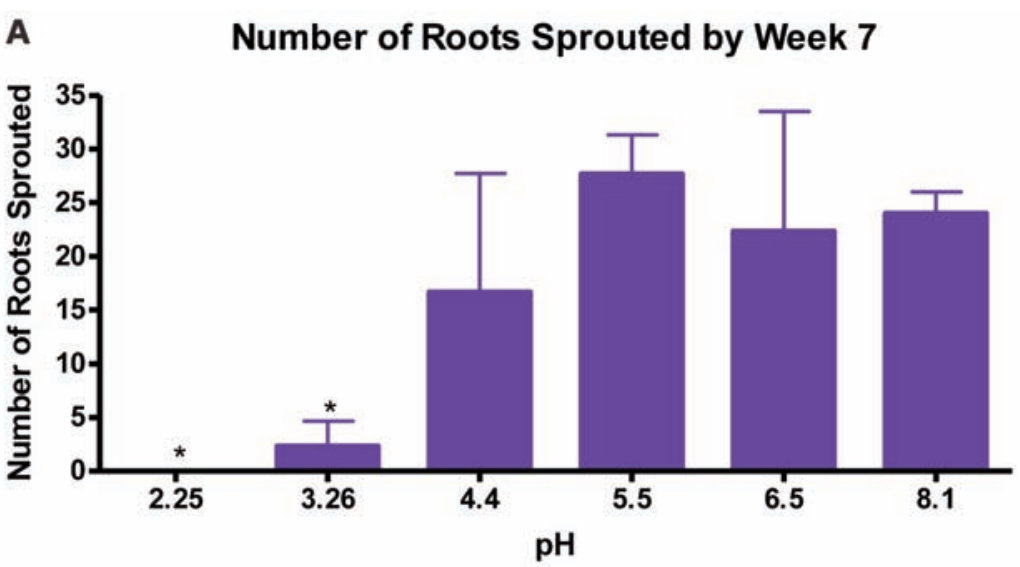

B Average Root Length at Week 7

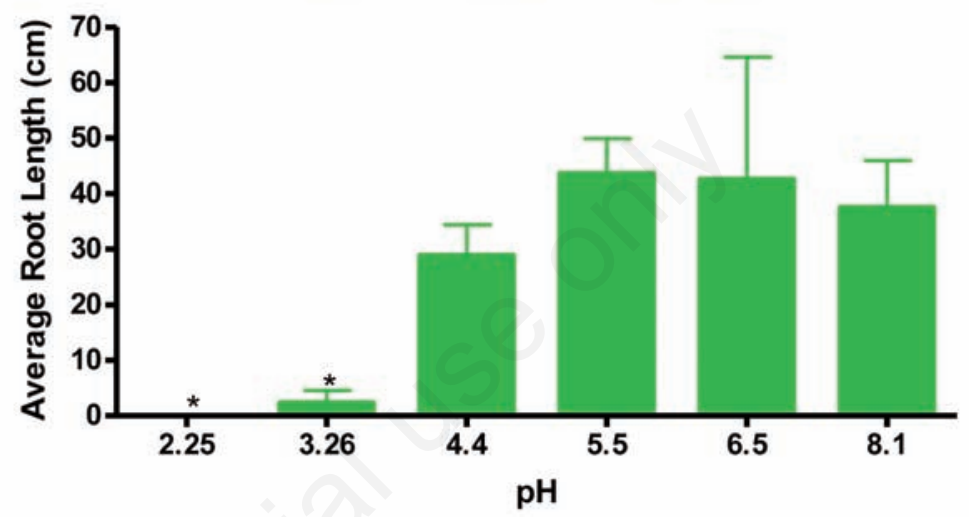

Figure 1. A) The average number of roots sprouted by cuttings of $S$. aureus cuttings as a function of the $\mathrm{pH}$ of the water after 7 weeks. B) The average cumulative root length of $S$. aureus cuttings as a function of the $\mathrm{pH}$ of the water after 7 weeks. ${ }^{*} \mathrm{P}<0.05$ versus all other $\mathrm{pH}$ except 2.25 and 3.26 .

We also did not investigate how the plants acidified their growing water when the $\mathrm{pH}$ was $>5$. We are unable to comment as to the mechanism by which this happened. Finally, the simulated acid rain was created with sulfuric acid, but now much of the acid rain is generated from nitric acid. ${ }^{15}$

Despite these shortcomings, the current study indicates that the root system of $S$. aureus thrives in moderate $\mathrm{pH}$ environments, including those that simulate current levels of acid rain in the eastern United States (pH 4.48.1). However, more acidic environments, as might occur in a highly polluted areas ( $\mathrm{pH} 2.3$ 3.3 ), inhibit root germination and growth. $S$. aureus, like many other plants, acidify their root environment.

\section{References}

1. Singh A, Agrawal M. Acid rain and its ecological consequences. J Environ Biol 2008;29:15-24.

2. Lehmann J, Solomon D, Zhao FJ, McGrath
SP. Atmospheric S02 emissions since the late 1800s change organic sulfur forms in humic substance extracts of soils. Environ Sci Technol 2008;42:3550-5.

3. Balasubramanian G, Udayasoorian C, Prabu PC. Effects of short term exposure of simulated acid rain on the growth of Acacia nilotica. J Trop Forest Sci 2007; 19:198-206.

4. Manisha Singh L, Singh SP. Studies of pH levels of simulated acid rain on Phasealus radiatus CVS. PS-16 and K-851. Biochem Cell Arch 2008;8:105-7.

5. Yoon JH, Lee DH, Woo KS. Effects of simulated acid rain on above- and below-ground growth of Liliodendron tulipifera L. seedlings. J Kor Forest Soc 2008;97:204-14.

6. Sirohi DS, Khan MAA. Effects of atmospheric pollution as acid rain on growth, chlorophyll content and root nodules of Trifolium alexandrium L. Crop Res (Hisar) 2006;32:528-34.

7. Aggangan NS, Dell B, Malajczuk N. Effects of soil pH on ectomycorrhizal response of Eucalyptus urophylla seedlings. New Phytologist 1996;134:539-46. 
8. Hasenstein KH, Evans ML. The influence of calcium and $\mathrm{pH}$ on growth in primary roots of Zea mays. Physiol Plant 1988;72: 466-70.

9. National Atmospheric Deposition Program. 2007 annual summary. Available from: http://nadp.sws.uiuc.edu/lib/data/ 2007as.pdf

10. Veron JEN. Mass extinctions and ocean acidification: biological constrains on geological dilemmas. Coral Reefs 2008;27:459-72.

11. Mengel K, Schubert S. Active extrusion of protons into deionized water by roots of intact maize plants. Plant Physiol 1985; 79:344-8.

12. Römheld V, Müller C, Marschner $\mathrm{H}$. Localization and capacity of proton pumps in roots of intact sunflower plants. Plant Physiol 1984;76:603-6.

13. Hinsinger $P$, Plassard C, Tang C, Jaillard B. Origins of root-mediated $\mathrm{pH}$ changes in the rhizosphere and their responses to environmental constraints: a review. Plant Soil 2003;248:43-59.
14. Li YH, Yan CL. Responses of the plasma membrane ion-pumping activities of Casuarina equiseti folia seedling twigs to acid rain. Xiamen Daxue Xuebao (Ziran Kexue Ban) 2006;45:131-5. Available from: http://www.dissertationtopic.net/doc/15791 05

15. Aikawa M, Hiraki T, Eiho J. Study on the acidification and pollution of precipitation based on a data set collected on a $0,5 \mathrm{~mm}$ precipitation basis. Atmos Environ 2008; 42:7043-9. 